\title{
“SPEAKING PROPERLY": LANGUAGE CONCEPTIONS PROBLEMATIZED IN ENGLISH LESSONS OF AN UNDERGRADUATE TEACHER EDUCATION COURSE IN BRAZIL
}

\author{
Rosane Rocha Pessoa ${ }^{1^{*}}$ \\ ${ }^{1}$ Universidade Federal de Goiás \\ Câmpus Goiânia, Goiás, Brasil \\ Julma D. Vilarinho Pereira Borelli ${ }^{* *}$ \\ ${ }^{2}$ Universidade Federal de Mato Grosso \\ Câmpus Rondonópolis, Mato Grosso, Brasil \\ Viviane Pires Viana Silvestre ${ }^{3 * * x}$ \\ ${ }^{3}$ Universidade Estadual de Goiás, \\ Câmpus Anápolis de CSEH, Goiás, Brasil
}

\begin{abstract}
This qualitative research was done in a class of English Oral Practice 2 in an undergraduate English teacher education course in Brazil. Grounded on the conception of language as social practice, the first author of this article developed a problematizing pedagogy focusing on race/racism and language as space of power. Resorting to class activities (a question in a written test, an oral test, and a feedback session) and the professor's diary, we analyzed the students' accounts about the subject and the meanings they constructed about language. Their accounts indicate that, when evaluating the subject, most of them highlighted the relevance of content, showing that they started conceptualizing language beyond form. Their accounts also suggest they were not using language, but making it.

Keywords: Language Education; English Teaching; Language Conceptions; Teacher Education Course.
\end{abstract}

\footnotetext{
"Holds a PhD in Applied Linguistics from the Universidade Federal de Minas Gerais. She is a Professor of English in the Department of Foreign Languages at the Universidade Federal de Goiás. Her e-mail address is: pessoarosane@gmail.com. ORCID: https://orcid.org/0000-0002-0538-2891.

** Holds a master's degree in Linguistics from the Universidade Federal de Goiás. She is currently a PhD student at the Universidade Federal de Goiás. She is a Professor in the Language Department of the Universidade Federal de Mato Grosso. Her e-mail address is: julmaborelli@gmail.com. ORCID: https://orcid.org/0000-00029456-8531.

${ }^{* * *}$ Holds a PhD in Linguistics from the Universidade Federal de Goiás. She is a Professor at the Universidade Estadual de Goiás. Her e-mail address is: vivianepvs@gmail.com. ORCID: https://orcid.org/0000-0003-22349046.
} 


\section{Introduction}

One of the most traditional views about language and language learning can be found in the play Pygmallion, by Bernard Shaw (2013). In the play, the professor of phonetics Henry Higgins makes a bet that he could pass off a Cockney flower girl, Eliza Doolittle, as a duchess merely by teaching her to speak and behave properly. After some months, she learns how to speak with an upper class accent and the experiment is a great success. However, at the end, Doolittle wonders what is to become of her life as she cannot go back to her life as a florist:

LIZA: Oh! if I only COULD go back to my flower basket! I should be independent of both you and father and all the world! Why did you take my independence from me? Why did I give it up? I'm a slave now, for all my fine clothes.

HIGGINS: Not a bit. I'll adopt you as my daughter and settle money on you if you like. Or would you rather marry Pickering?

LIZA [looking fiercely round at him]: I wouldn't marry YOU if you asked me; and you're nearer my age than what he is.

HIGGINS [gently]: Than he is: not "than what he is."

LIZA [losing her temper and rising]: I'll talk as I like. You're not my teacher now. (Shaw, 2013, p. 83, quotes in the original, italics added)

Were we interested in the plot, we could discuss the artificial creation of an individual, not by chance a woman, or Doolittle's life prospects after the experiment, but here we are more concerned with her language training. Today, it seems very anachronistic to think about phonetics training, but we keep wondering if this experiment is so markedly different from what foreign language teachers are still doing in classes when we address linguistic aspects, moments which are very frequent in many language teaching contexts nowadays. Indeed, is it not still common to do what Higgins does in the excerpt above, that is, correct a language mistake when something relevant has been said, no matter how gentle the correction has sounded? A hundred years have passed since the play was published, and we are still teaching our students to "speak properly" (Shaw, 2013, p. 35). Why is the language system still so present in our language lessons? Why is standard language still so strong when it is as hybrid as any other linguistic repertoire?

Being challenged by these two questions, we have been trying to walk away from linguistic aspects in our lessons, and in the second semester of 2014 the first author of this article had an opportunity to do this, which arose from a thirteen-student group of English Oral Practice 2 of the undergraduate English teacher education course of a federal university in the Midwest of Brazil. In the first three months the theme race was worked on, and the students watched "The Help", directed by Tate Taylor (2011). The professor brought some of the film memorable quotes to be discussed. Here is one of the quotes by the maid Aibileen Clark: "Miss Leefolt got so much hairspray on her head, she gonna blow us all up if she light a cigarette". The students got so curious about African American Vernacular English that "language" became the topic of the following month, and 
its work became the object of this study. Thus, our main aims in this paper are twofold: to discuss the students' accounts about the subject and to problematize the meanings about language the students built along the 64 hours of the subject. So, the questions that guide this study are: 1) What are the students' perceptions about the subject? and 2) What meanings about language did the students build throughout the subject?

We are aware that the focus on content is not a novel pedagogic practice, and it is not our aim to claim for novelty, but rather to discuss an English teaching problematizing practice guided by the attempt to understand who we are in this social world characterized by diffuse power relations, instead of how we tackle language form to communicate.

\section{Language and language teaching}

The formalist tradition in the field of modern linguistics was an attempt to bring order to the chaos which constitutes speech or everyday communication. According to Harris (2010a), modern linguists partially renamed and greatly complicated the "rules of grammar" that were invented or formulated by grammarians with the aim of simplifying morphology and syntax for the benefit of learners. In the field of modern language teaching, the focus on form has been prevalent since it was conceived in terms of method. Even today, many language textbooks are organized according to key grammatical points in a certain sequence, presupposing that we cannot engage in communication unless we have acquired a linear set of grammar rules; it is as if they were a precondition of communication.

However, we, language teachers, have been challenged to go beyond this formalist tradition by many authors, such as Canagarajah (2007, 2013), Cavalcanti (2013), Harris (1998, 2010a, 2010b), Hopper (2002), Jacquemet (2005), Kumaravadivelu (2012), Makoni \& Pennycook (2007), Pennycook (2007), and Thorne \& Lantolf (2007). Harris has been working on the development of an integrational approach to signs and semiological systems, and hence to all human communication, since the 1980s. According to him, this approach

involves looking at current educational practice, together with the whole history of linguistic thought from Plato down to the present day, in a perspective that differs radically from the orthodox view presented by traditional authorities. (Harris, 2010b, para. 1)

The basic assumption underlying this approach is that

[t]here are no context-free signs, whether verbal or non-verbal. Contextualization is a complex activity, still too often neglected and poorly theorized. It is not just a function of the immediate situation, but of the entire communicational experience of the participants. The act of 
contextualization is the act by which the sign is identified as a sign. No contextualization, no sign. (Harris, 2010a, para. 4b)

In other words, the linguistic sign alone cannot function as the basis of an independent form of communication, but it "depends for effectiveness on its integration with non-verbal activities of many different kinds" (Harris, 2010a, para. 3a). The author also argues that linguistic acts are events in people's lives as any other events that make up all we do in the course of a day. It follows that instead of language-users, we are language-makers.

Makoni \& Pennycook (2007, p. 1) also deconstruct the conception of language by arguing that "conceptions of languageness and the metalanguages used to describe them are inventions", resulting from "the Christian/colonial and nationalistic projects in different parts of the globe". They mean that the process of "identifying, delimiting, mapping, and naming languages in the colonies" and "even the ways they were described in grammars and dictionaries were all heavily influenced by an ideology of racial and national essences" (Makoni \& Pennycook, 2007, p. 2). As Thorne \& Lantolf (2007) summarize it, mutable, local and contingent communicative repertoires were reified into categorical linguistic varieties by historical and political processes. Accordingly, Makoni \& Pennycook (2007, p. 4) argue that any critical linguistic project should involve rethinking language in the contemporary world, a process that involves comprehending "the interrelationships among metadiscursive regimes, language inventions, colonial history, language effects, alternative ways of understanding language and strategies of disinvention and reconstitution".

If languages and metalanguages are fictional constructs and if there are no context-free signs, why are we still teaching English, for example, as if English were territorialized - American or British English - and as if it were "one system" that could be acquired by students? We try to bring hybridity under control by teaching standard English, but a "standard language" may be one of the most compelling examples of linguistic invention as it is assumed to be a neutral and stable norm widely shared by the language speakers. However, why is it closer to the repertoires of dominant groups? According to Harris (2010a, para. 6c), "standard language" and "rules of grammar" are "pedagogic fictions, maintained chiefly for educational and political reasons, and serving to disguise the endless variety of integrational patterns that are to be found in everyday human interaction".

Pennycook (2007, p. 97), in an article focusing on the myth of English as an international language, argues that standard English "produced a metalanguage rather than a language, or put another way, the standardization of English produced not so much standard English but rather discourses about standard English", since "no one actually speaks a standard language" (Milroy, 1999, p. $27^{1}$ cited in Pennycook, 2007, p. 97). According to Milroy (1999, p. 18), "any variety delimited and described by the linguist is an idealisation" and "the usage of an individual speaker will not conform exactly to that idealisation". 
Canagarajah (2013, p. 108) argues that even the attitude to written English as being standardized and neutral is increasingly being questioned by multilingual scholars, since it is "based largely on the norms of Inner Circle ${ }^{2}$ communities and distant from the norms of multilingual communities". He adds that the "universality of Standard Written English or written language is also treated increasingly as a language ideology" (Canagarajah, 2013, p. 109) and "cannot be treated as a monolith, masking the diversity that is already there in written discourse" (Canagarajah, 2013, p. 109).

In order to overcome static notions of language, Makoni \& Pennycook (2007) invite us to relocate language learning from an additional (referring to the linguistic boundaries underlying notions of second language acquisition or second language learning) to a transidiomatic practice. Jacquemet (2005, pp. 264265 , emphasis in the original) uses the term

transidiomatic practice to describe the communicative practices of transnational groups that interact using different languages and communicative codes simultaneously present in a range of communicative channels, both local and distant.

However, Makoni \& Pennycook (2007) argue that this practice also characterizes precolonial times. Taking the matter further, Canagarajah (2007) invites us to return to the ways language was practiced in precolonial/premodern times and adapt them to contemporary social conditions. According to him, the fluidity and hybridity of precolonial forms of communication are much more complex nowadays not only because migration and relocation have connected distant communities, but also because new technologies have fostered multilingual interaction. Canagarajah (2007, p. 234) is inspired by Kubchandani $(1997)^{3}$ to affirm that "community" for local people in India, for example, "was based not on unitary languages, but a shared space where many languages live together" and that "their language practices were based on negotiation rather than on fidelity to unitary constructs". Concerning English, Canagarajah (2007, p. 235) rejects scholars' proposals such as lingua franca English as a common dialect that speakers of World Englishes can use to facilitate communication among each other and suggests that we "move towards radical pluralism, whereby speakers of all local varieties can negotiate their differences for effective communication". He argues that these differences should be negotiated by means of pragmatic strategies such as codeswitching, speech accommodation, interpersonal strategies (repair, rephrasing, clarification, gestures, etc.), and attitudinal resources (patience, tolerance, humility, etc.) to negotiate differences.

In this world of disinvented languages, Canagarajah (2007, p. 237) believes that language teaching should focus on "negotiation strategies"; learners should "assume difference in communication" and be oriented towards "sociolinguistic and psychological resources that help negotiate differences"; and teachers should "move away from an obsession with correctness". In other words, learners should 
be prepared to engage in communities of practice and collaboratively achieve communication through the use of pragmatic strategies. By doing this, they may develop a repertoire of codes and an understanding of the fluidity in codes they see around them, and they may learn to shuttle between communities instead of wishing to join one community.

To Hopper (2002, p. 4), a realistic goal for the teaching of languages "is surely to study what happens when we communicate through language". Inspired by Hopper (2002), Thorne \& Lantolf (2007, p. 189) propose a linguistics of communicative activity

based on a view of language as a historically contingent emergent system, one that provides a repertoire of semiotic devices that people can use to realize their communicative intentions, to interpret the communicative intentions of others and, perhaps most importantly, to foster the conditions of possibility for transforming self and community.

In the same line of thinking, Cavalcanti (2013) quotes Blommaert $\left(2010^{4}\right.$, p. 3), according to whom "the globalization phenomenon with its landscapes in constant movement requires a theory of a moving language for a moving society, which characterizes a critical social science of language". To her, in this context, linguistic education is not as simple as teaching linguistic content. It requires a sophistication that depends on being sensitive to students and their linguistic production. In fact, linguistic education should focus on how we use language. When we communicate, are we producing discourses that favor plurality in the world? Are we being prejudiced or having condescending attitudes (Cavalcanti, 2013)? Are we enhancing our abilities to carry out activities to improve our lives (Makoni \& Mashiri, 2007)?

Based on this discussion, we will analyze an experience of problematizing some modern ideas about language in English lessons at the undergraduate level, lessons in which fluidity and hybridity were assumed and negotiation was the most valued strategy, but first we will describe the study.

\section{The study}

The research context was a subject, English Oral Practice 2 (Prática Oral 2 de Inglês), held in the second semester of a four-year undergraduate course of English teacher education (Curso de Letras: Inglês) at the Universidade Federal de Goiás. In this undergraduate course, the students not only reflect on language and language education, but are also prepared to teach English.

Two main themes were discussed during the four months (64 hours) of the subject, from August to December 2014: "race/racism" and "language as space of power". The main semiotic resources used in class were: 1) "Questions of identity", a two-page text that defines "identity"; 2) Chimamanda Adichie's biography as preparation for the video "The danger of the single story"; 3) Carolina Maria de Jesus' biography as a preparation for reading some diary entrances from the 
book "Child of the Dark"; 4) "I, Too", a poem by Langston Hughes; 5) the video "Revisiting an experiment on race"; 6) the film "The Help" by Tate Taylor; 7) the text "Language" from the book "Teaching to Transgress" by bell hooks ${ }^{6} ; 8$ ) the video "An incredible conversation with Paulo Freire"; 9) the video "Three ways to speak English" by Jamila Lyiscott; 10) a text titled "History of Portuguese Language in Brazil". The lessons were characterized by discussions, and the English language was used in most interactions. Portuguese was used when the students could not express themselves in English and, we see it as a pragmatic strategy, that is, as part of the fluidity and hybridity that characterize all forms of communication. Detailed information about the nine female and four male participants is shown in the following chart:

Chart 1: Information about the participants

\begin{tabular}{|l|l|l|l|}
\hline Ficticious names & Age & Colour/race & Occupation \\
\hline Anita & 27 & Mulatto & Private English Teacher \\
\hline Caroline & 20 & White & Student \\
\hline Cecília & 22 & White & Student \\
\hline Celina & 21 & White & $\begin{array}{l}\text { Event promoter and Private English } \\
\text { Teacher }\end{array}$ \\
\hline Daniela & 18 & Mulatto & Student \\
\hline Felipa & 18 & Mulatto & Student \\
\hline Handel & 38 & White & Student \\
\hline Lavínia & 23 & Mulatto & Saleswoman \\
\hline Lucas & 18 & Mulatto & Student \\
\hline Marisa & 18 & Mulatto & Student \\
\hline Pedro & 17 & Mulatto & Student \\
\hline Renata & 31 & White & $\begin{array}{l}\text { Administrative employee } \\
\text { in a TV network }\end{array}$ \\
\hline Tiago & 24 & Mulatto & Student \\
\hline
\end{tabular}

${ }^{\star}$ All of them are fictitious names chosen by the participants.

Since we studied a situated activity in its natural settings, attempting to make sense of, or interpret, it in terms of the meanings the participants bring to them, we can say it is a qualitative research (Denzin \& Lincoln, 2008). The authors (2008, p. 5) also that, in order to "make the world visible", "more than one interpretive practice is necessary". Thus, the representations we used to have a better understanding of the students' accounts about language were: 1) a question in the last written test ${ }^{7}$ (henceforth QWT), done in English, in which they were supposed to discuss their experience of taking part in the subject in a paragraph of at least ten lines; 2) the last oral test (henceforth OT), done in English and audio recorded, in which they were asked to make a three-minute speech about a topic related to the ones studied in class; 3 ) a feedback session (henceforth FS), done in Portuguese and audio recorded, in which they gave their opinion on the 
subject content, their learning, and the problems faced; 4) the professor's diary (henceforth PD), written in English after the feedback session, in which she wrote her impressions on the subject. All the students took the written test and the oral test, but three missed the feedback session: Caroline, Lavínia, and Lucas.

We have not transcribed the participants' accounts verbatim, as repetitions, incomplete sentences, introductory expressions, and fillers were eliminated. However, the content of the accounts was not modified, and when mistakes could make the sentence incomprehensible, we wrote the standard form in brackets (for example, [feeling] was inserted when the student used "fell", the past of "fall").

As Canagarajah (2007, p. 237) suggests, we tried to "move away from an obsession with correctness" and focus on negotiation strategies in the subject. In every class, most of the students, with different levels of English, engaged in the discussions and used codeswitching, interpersonal strategies, and attitudinal resources (Canagarajah, 2007) when discussing the two topics "race/racism" and "language as space of power". Our main interest was not language or metalanguage, but rather "the multiple investments people bring to their acts, desires and performances in 'English"' (Pennycook, 2007, pp. 110-111, emphasis in the original).

\section{Learning language and "learning about ourselves"}

Generally, English Oral Practice 2 focuses on everyday communication and some grammar points, as most students are beginning to develop their knowledge about English, ${ }^{8}$ so a limited linguistic agenda was also part of the subject under analysis here. However, there was no attempt to bring order to the "chaos" which constitutes speech:

[1] Instead of proposing trivial communication activities or focusing on linguistic aspects as I used to do in Prática Oral 2 de Inglês, this semester I decided to pose a challenge to this group and work with authentic texts as we do from the second year on. The students in this group seemed to be able to speak their minds in English and I thought that was enough. (PD)

In the question of the written test about their experience in the subject, one student affirmed it was a bad experience and twelve students declared the lessons were relevant for them: five focused on the content; four focused on the content and linguistic aspects; and three focused on linguistic aspects.

The five students who focused on the content were Anita, Cecília, Caroline, Lavínia, and Tiago. Anita highlighted the importance of discussing the topics "prejudice, racism and language as an instrument of power". Cecília affirmed that she "understood that speaking english is all about practice" and that the texts made her think and wish to talk. Caroline stated she opened her mind to things she had never thought before, such as "the relationship between language and domination". Lavínia pointed out the lessons made her reflect about herself and about language. In the following account, it is clear that Lucas was not "using" language, but "making" it (Harris, 2010a), that is, he was building his identity 
as a result of classroom interaction; his behaviour towards what/who is different because of the linguistic and discursive repertoire developed in the classes:

[2] I thought the teacher would teach us grammar, phonemic transcription and, mainly, dialogues. I was wrong. We learnt about many things that take part in our lives, but we usually don't notice. For example, identity and prejudice. [...] Today, I conclude this subject with an open mind, accepting people's point of view. Instead of judgement, it is better try to understand the others reality and context. (QWT, Lucas)

The same claim to particular identities by means of semiotic restructuring (Pennycook, 2007) can be noticed in the following accounts. However, they also mentioned their linguistic improvement and these students comprise four out of the thirteen participants: Renata, Tiago, Marisa, and Pedro Henrique. Renata pointed out: "I could see my mistakes and try to correct them", but concluded her text highlighting her new conceptions developed in the subject: "[...] when I become a teacher I hope that I can change the fell [feeling] of [my] students about learned [learning] and language, the same fell [feeling] that I fell [felt] in this subject". Tiago, Marisa, and Pedro Henrique highlighted changes in their views:

[3] The way we have been using language to study and discuss topics related to identity and race has expanded my views about myself and my relationship with the others. The reading and writing activities are helping me to develop my communication skills, while having conversations with my classmates improves my confidence about speaking in English. I feel the subject is helping me to be a better English speaker, but also a better person. (QWT, Tiago)

[4] In Prática Oral 2 I had a lot of new discoveries and they for sure improved my English and me as an human being. On this subject I learnt a bunch of things about racial prejudice and other kinds of prejudice. Mainly about racial prejudice I got new informations that changed my opinions about affirmative actions, making me totally in favour of quotas nowadays. [...] I also started to think so much more about the language and its influence on the society. See the language as a strategy of power and know all the consequences of a single sentence might have in a person or in a society in general makes me think how we are responsable for do lots of good things and bad things in the world. And for sure I can feel my English better, and that I am with a bigger vocabulary wich improve a lot my capacity of talk in English and makes me less introspective when I am using English. (QWT, Marisa)

[5] During this semester I learnt a lot of things. I did not improve just my English, but also myself. I learnt how language is strong and can affect people. It was interesting because I could link it to my experience when I was younger and overweight. I realized that language has power and we use it to do good or bad things. I am a little bit shy but those topics were so interesting that I lost my shyness to show my opinion. (QWT, Pedro Henrique)

Other three students laid more emphasis on linguistic aspects in the question of the written test: Felipa, Celina and Daniela. Felipa affirmed that, although 
she still had difficulty to organize sentences in her mind, she "was able to watch documentary, movie and series without subtitles or with English subtitles". Celina focused on her feelings in relation to speaking: "In the first time I was afraid because I feeling that I wasn't very good in English, but now I saw that I improve a lot and [...] I am not afraid more and I speak, and ask questions, and I use more language". Daniela was a bit vague about the content and clearer about linguistic aspects:

[6] [...] this subject helped me a lot. I had the chance to talk in English with my colleagues, and I am sure that I improved it. I learnt how to discuss ideas in English, we saw many videos about language that show us some problems that we have to deal. We also leant how to pronunciate the words correctly, and I think that I can speak better than before, I lost the fear of make mistakes. (QWT, Daniela)

In the diary, the professor highlights how confident Daniela was to talk about her new language conceptions in the last oral test, that is, her speech was a performative act in the sense that she performed what she had understood about language. In general, these participants' accounts suggest that the professor's attempts to transgress the formalist model of teaching was seen as positive and promoting students' growth. It is interesting to see that Tiago, Marisa, Pedro Henrique, Cecília and Daniela mention, in their accounts, that they felt more empowered to speak English, that is, they did not simply improve linguistic skills. Students made language in the sense that they were the actors of their actions, not only users subjected to an invented, external, superior structure. The teacher's practice went beyond linguistic structure and affected them as people and, consequently, as future language teachers, that is, it seemed to have fostered "the conditions of possibility for transforming self" (Hopper, 2002, p. 4). Handel was the only student who had difficulty adapting to the subject design:

[7] After I saw that speaking was around the point that I could explain about some themes I didn't like this way of expression ideas because it was difficult to me develop new words, so Prática Oral 2 de Inglês wasn't a good experience for me. (QWT, Handel)

In the feedback session, possibly because he was saying it to the whole class and to the professor, firstly he made this analysis about the content:

[8] [...] everything makes us reflect more, they are part of our reality, they exist, they are not invented. [...] It is content that favours speech since it deals with things we can see, measure, analyse". (FS', Handel)

He also said "I liked all the texts that we read and learn, [...], but I think that we could have had more dynamic speaking activities". He complained about not being able to "take the turn" and the reason he gave was that he never practiced English out of class, so he did not have enough vocabulary to discuss, as his 
colleagues did. In fact, most of the discussions were open, so that everybody could listen to each other's opinions, but we believe he wanted more controlled language activities done in pairs and in small groups. The professor argued that she thought his English was good enough to talk about any topic and that when he "took the turn" he spoke more than anybody and was not objective, as he did many times in class when the professor asked his opinion about a topic. His difficulty, as we can understand from his accounts and attitude in class and was confirmed by him, was with interaction as he seemed to disregard his listeners when he spoke.

At the end of his account in the feedback session, he said he was "distant from his colleagues", "stayed in his corner", and it happened because he was "introspective". Marisa and Pedro Henrique, in the extracts [4] and [5], also mentioned their own introspection, but they affirmed that with the lessons they were able to overcome it. As we can see, the different approach to language practice brings some complexities to the classroom environment. Similar to what happens in the real world, interacting may be difficult to some people, and adopting this perspective involves the risk of causing some discomfort. If the lessons had focused on grammar points with controlled practice, Handel would probably have felt more comfortable, but language is far from being this safe place we normally try to build in class. According to Souza (2011), we have to learn to deal with complexity and dissention; thus, teachers should involve students in the confrontational and tough process of different interpretations and values.

The fact that most students highlighted the content exploited in the lessons indicates that they were conceptualizing language differently from what is usually done in language education, that is, beyond form. Besides, some of them were explicit about this conceptualization. Lavínia started to "see language as emotion". Cecília understood that "speaking english is all about practice", and Marisa started to see language "as a strategy of power". The same happened in the oral test, as we will see next.

\section{Disinventing and reconstituting language concepts}

In the oral test, they had to speak about a topic related to the ones discussed in class for about three minutes, so this activity will be referred to as "speeches" henceforth. Caroline chose to speak about "racism", Celina and Anita spoke about "prejudice" in general and the other ten spoke about "language". These ten speeches will be analyzed here. We would like to highlight that, from all the semiotic resources used in class, the three that seemed to have inspired the students the most and were mentioned in the speeches were "Language" by hooks (1994), "An incredible conversation with Paulo Freire" (1996), and "Three ways to speak English" by Lyiscott (2014). The three of them conceptualize language as power and emphasize that we should fight language domination.

The relationship between language and power was the topic of all the speeches about language, except for Renata's. Lucas focused briefly on two topics and one of them was the oppression expressed in gender marking in Portuguese: 
"when we want to talk about women and men, we use the word in a masculine form, so we are repressing the women". In the same perspective, Marisa spoke about gender differences in language: first, she criticized the idea that women talk more than men and showed some studies which indicate that in work situations or in university discussions, men talk more and do not accept being interrupted by women. Then, she presented a study which suggests that mothers from middle and low classes prefer to use standard English to talk to their children so that they can have more opportunities in the future, while men do not have this concern because they do not raise their children. She analyses these language behaviors that can be translated into imposition and at the end emphasizes that "language is a really powerful weapon". Handel compared the linguistic situation faced by African slaves who went to America with the linguistic situation of Brazil when the Portuguese colonizers arrived, pointing out the oppression represented by the action of the Portuguese people to use the Tupi language in order to enslave Brazilian indigenous peoples. These accounts suggest that these students suspect that it is necessary to rethink language in the contemporary world, as defended by Makoni \& Pennycook (2007), which involves comprehending, among other aspects, our colonial history.

Cecília, Pedro Henrique, and Lavínia talked about the effect language had in their lives. A detailed discussion on language as a space of power, focusing on these three participants can be found in Pessoa \& Urzêda-Freitas, (2016). Cecília recollected that her school colleagues were "mean" to her and used to "call her a lot of names" because she was "a little bit overweight and I looked like a little boy". Pedro Henrique started gaining weight when he was 7 and he remembered: "people started to say really bad things to me, they sang music to me, saying that I was fat, and it affect me so much". He added that later he "became a vegetarian" and "stopped eating properly [...] I had anorexia". Lavínia had prepared another topic, but, inspired by Cecília and Pedro Henrique, she also talked about an experience she had with a teacher. She stated that the quote by hooks (1994: 167) "words impose themselves, take a root in our memory against our will" made her think of "language as emotion" and remembered that when she lived in Portugal a Portuguese teacher told her she was not good at writing:

[9] [...] and then once she said me, "you don't need to learn to write because you will not need to learn it" and that words made me feel very bad about me and [crying] about what I am today and then I can show to you that I am here today to show that I passed through this [crying and choking up]. (OT, Lavínia)

Besides telling these incidents, they made some reflections about language at that moment:

[10] [...] it's something that I really don't want to my kids, to my son or my daughter in the future, but I think our society needs to change. (OT, Cecília) 
[11] [...] some people say that we are over the animals because we can talk, but is it a good thing to do this with language, to treat people like this? Animals don't do these things. We can do incredible things with language, we can praise people, [...] it makes people feel better, and this class make me think about it. (OT, Pedro Henrique)

[12] All this words that I heard make me feel what I feel today, what I am today, and this words can be good or not, but it change me, and I think that we had to measure our words when we are talking with a person because as a teacher that we all will become we had to think about it as a method of teaching in school. (OT, Lavínia)

It is naive on their part to think that we can stop being oppressive, but it is important that the students recognize "how they [the oppressors] shape it [language] to become a territory that limits and defines, how they make it a weapon that can shame, humiliate, colonize" (hooks, 1994: 16) and that these students try to resist it. As was concluded in Pessoa \& Urzêda-Freitas' (2016) article, the fact that the students decided to talk about these offenses publically and position themselves against them indicates they were recontextualizing them more affirmatively.

The other experience Cecília talks about in her speech is related to the strict education she had as a child:

[13] My dad is very attached to grammar, he's very strict, and since I was a child, he always been correcting me about some grammar mistakes and I was afraid to talk to my dad [...], it was very hard to me because I felt that we couldn't get close and even today he still lives with me and I am afraid of talking to him because I fell [feel] that he can repress what I'm saying and he thinks that because of the fact that I do Letras [...] [and] I have to have exemplar Portuguese. (OT, Cecília)

She thinks there is an irony in that because it was in her undergraduate course that she learnt she did not need to be formal at home. However, after beginning the subject she changed her behavior: "I started to talk more, even he [her father] corrects me, I started to talk more with him, and it was really important to me". Here we can see how Cecília seems to have grown empowered to challenge a traditional language conception.

Four other students also made speeches relating standard languages to other languages: Felipa, Lucas, Daniela and Tiago. Felipa spoke about an experience of linguistic discrimination that two black kids suffered in elementary school. They moved from the South to the North of the United States and, even though they started studying at a school called Martin Luther King School, where colour was not an issue, the teachers did not accept their African American English and said that they were "unteachable". Felipa said that, in the video, it is defended that "standard English is a dialect" and, though it should be taught at schools, other ways of speaking cannot be forgotten, an idea which finds resonance in Freire's (1996) interview. Similarly, Lucas, in the second topic of his speech, criticized 
the fact that just formal language and grammar rules are taught at schools and affirmed that teachers should teach their students

[14] that language is not just it. It's to express what you're feeling, your thoughts $[\ldots]$ and I think that's a bad thing because I think that's the reason why there are more Pasquales [a Portuguese teacher who values a normative approach to language] than Jamilas [Jamila Lyiscott] [laughs]. (OT, Lucas)

Daniela talked about her own experience with language before and after she started studying at university and sounded very enthusiastic about her learning. She affirmed:

[15] [...] when I was in high school, I hardly ever thought about language, I just thought about grammar and at university I started to see with other eyes language, I started to think how it affect us, [...] I start to think about language as power, as oppression [...]. I think it's too strong, here in Brazil [...] we think that we have to correct all the people all the time, we have to speak only in standard Portuguese here and I think bell hooks, the text I liked very much and she showed to me that I can speak informal Portuguese and I'm not ignorant because of it. [...] During this year, I learnt a lot of things about language, [...] it's the way we can show to people how we think, how we act and I think it's good to us have persons like Jamila, like bell hooks, like Chimamanda, who has no fear to show this differences, who show to us that nobody is equal, so why language has to be equal to everybody? (OT, Daniela)

In this account, Daniela shows she is disinventing and reconstituting her conception of language as well as recognizing the importance of difference. Tiago, in his speech, connects linguistic prejudice and racism in a very surprising account that shows that difference is in ourselves. He said that once in class a student asked if he were a racist person and he said "no, I am not a person that has prejudice". He continued:

[16] I had this conviction about myself until something very funny happened. [...] I did not realize that I was a racist person. Even though I was raised among black people, my grandmother is black, I have a lot of cousins that are black. [...] sometimes I fix computers for people, and since in the morning I'm here, most of the time the people leave the computers in my house and I fix them and they just pick it up later and this guy, he left his computer and I fixed for him, and two weeks later, it was in October, he called me to ask me to install a printer for him and in my head, because he was so polite, he was speaking standard Portuguese, and in my mind he was white [laughs], and I was so shocked when I arrived at his home and I saw that he was a black man. I felt so bad about this because "oh, my god, I'm totally racist! This is horrible!" But in other hand, it was an awesome experience because it made me realize that this prejudice was inside of me and for a few seconds I felt like those kids in that experiment on race [laughs], like "which doll is the polite doll? Which doll speak standard Portuguese? [laughs] Which doll has money 
to pay me for the service?" [...] now I'm aware of that, and this was a great opportunity because the university made me realize that I had prejudice even though it was hidden and now I think that I changed my mind about these ideas on race. (OT, Tiago)

Here, Tiago perceives he has internalized discourses of standard English as belonging to dominant groups, represented by "white people". Renata was the only student who did not link language to power. She resorts to the Lyiscott's (2014) speech to explain that she uses different ways of speaking in different contexts. It is relevant the fact that she talks about "the correct way to speak" not referring to grammar, but to context, implying that if your language is appropriate to the context, it is correct, which is in keeping with the theorizations previously discussed (Harris, 1998).

It is true that students were required to talk about themes linked to the ones discussed in class, so one could argue that they were left with no other option than to do what they did. However, their speeches indicate that they accepted the challenge to go beyond the formalist tradition. In fact, they talked about linguistic acts as events in their lives (Harris, 2010a), events which involve the power of men over women, personal offense, and language discrimination. Besides, their accounts suggest that they locally reinvented their language conceptions based on their experiences: as power, as emotion, and as practice.

\section{Final words}

In this study, we aimed at discussing the students' accounts about the subject English Oral Practice 2 and the meanings about language they built along it. The students' accounts about the subject suggest that twelve students found the lessons relevant and, when evaluating them, five of them referred only to the content, four focused on the content and linguistic aspects and three concentrated on linguistic aspects. Only one student affirmed the subject was not a good experience for him, because, even though he liked the texts, he had difficulty interacting. Problems like this are part of the macrocosm which the classroom represents, and an even participation cannot be guaranteed by a teacher, nor can he/she assure that everybody be heard. Thus, this difficulty Handel had indicates that genuine interaction prevailed in most classes, and the fact that the majority of them highlighted the content means they were conceptualizing language beyond form.

Concerning the meanings about language, nine out of thirteen chose to make speeches that related language to power. Some of them gave personal accounts and others brought points of view about language that are far from the neutral idea that "language lessons should just teach the language". In fact, Cecília summarized what many of them said in the feedback session: "we're not just learning English, we're learning about life". It is confirmed by these accounts: "I have learnt that racism exists and it is hidden in our society" (Tiago); "We have to learn what racism is and change how we act, what we say" (Renata); "I 
have learnt the power of language" (Pedro Henrique); "If I don't want my son to have prejudice, I have to set a good example" and "I was against [affirmative] quotas, now I think they're necessary" (Marisa); "I thought linguistic prejudice was normal, everybody had to accept" (Felipa). Anita's and Daniela's last remarks suggest that they learnt that classroom language should not be different from how language is used in life:

[17] It was very good to discuss language as instrument of power, to discuss prejudice, racism, [...], when we use English to represent what we think, to express what we want, to convince the others, we are using real language. (FS, Anita)

[18] It's spontaneous, I go there and say what I'm thinking, what I learnt, what I feel. (FS, Daniela)

We believe that, in the subject English Oral Practice 2, students accepted the challenge to take diversity seriously, not only because of the positions they took about the topics, but especially because of their reconceptualizations about language and language learning. Instead of learning to "speak properly" (Shaw, 2013, p. 35), most of the time they were "performing identity with words" (Pennycook, 2007, p. 110), both when they accepted the challenge of discussing social themes and when they resisted them. We like to think that instead of teaching English, the participants were doing things with English, that is, they were "Englishing" (Pennycook, 2007, p. 111).

\section{Notes}

1. Milroy, James. (1999). The consequences of standardization in descriptive linguistics. In T. Bex and R. J. Watts (eds.), Standard English: The Widening Debate. (pp. 16-39). London: Routledge.

2. The Inner Circle is one the three concentric circles in the sociolinguistic profile of English categorized by Kachru (1985). The other two are the Outer Circle and the Expanding Circle. The Inner Circle refers to the traditional basis of English spoken by native-speakers (e.g. USA, UK, and Canada). In the Outer Circle, English is spoken as a second language using new norms shaped by new sociocultural and sociolinguistic contexts (e.g. India, South Africa and Nigeria). Expanding Circle includes countries where English is spoken as a foreign language by nonnative speakers of English (e.g. Brazil, Turkey, and Japan).

3. Khubchandani, Lachman. M. (1997). Revisualizing Boundaries: A Plurilingual Ethos. New Delhi: Sage.

4. Blommaert, Jan. (2010). The Sociolinguistics of Globalization. Cambridge University Press.

5. As a previous study (Pessoa \& Urzêda-Freitas, 2016) was carried out in the same context, some information concerning the context and the participants is repeated here.

6. We have not capitalized bell hooks' name because this is how she has opted to write it. 
7. In spite of being a test, we believe they felt comfortable to give their opinion as these opinions were later confirmed in the speeches and the feedback session.

8. The only requisite to participate in the subject is being approved in English Oral Practice 1, but no test is done to level students according to their language knowledge.

9. As the feedback session was held in Portuguese, we have translated their accounts into English.

\section{References}

Canagarajah, Suresh. (2007). After disinvention: possibilities for communication, community and competence. In S. Makoni and A. Pennycook (eds.), Disinventing and Reconstituting Languages (pp. 233-239). Clevedon: Multilingual Matters.

(2013). Translingual Practice: Global Englishes and Cosmopolitan Relations. New York: Routledge.

Cavalcanti, Marilda C. (2013). Educação linguística na formação de professores de línguas: intercompreensão e práticas translíngues. In L. P. da Moita Lopes (ed.), Linguística Aplicada na Modernidade Recente (pp. 212-226). São Paulo: Parábola.

Denzin, Norman K. and Lincoln, Yvonna S. (2008). Introduction: the discipline and practice of qualitative research. In N. K. Denzin and Y. S. Lincoln (eds.), The Landscape of Qualitative Research (3rd edition) (pp. 1-43). Thousand Oaks, CA.

Freire, Paulo. (1996). An Incredible Conversation with Paulo Freire. Retrieved 24 April at https://www.youtube.com/watch? $\mathrm{v}=\mathrm{aFWjnkFypFA}$.

Harris, Roy. (1998). Introduction to Integrational Linguistics. Oxford: Pergamon.

. (2010a). Integrationism: a very brief introduction. Roy Harris Online. Retrieved 14 April at http://www.royharrisonline.com/integrational_linguistics/ integrationism_introduction.html.

(2010b). Integrationism. Roy Harris Online. Retrieved 14 April at http:// www.royharrisonline.com/integrationism.html.

Hooks, bell. (1994). Teaching to Transgress: Education as the Practice of Freedom. New York: Routledge.

Hopper, Paul. (2002). Emergent grammar: gathering together the fragments. Talk at the Institute for Applied Linguistics, Penn State University, 10 July.

Jacquemet, Marco. (2005). Transidiomatic practices: language and power in the age of globalization. Language \& Communication 25: 257-277. Retrieved 27 April at http://www.letras.ufrj.br/linguisticaaplicada/gtidentidade/docs/recom/jaquemet. pdf.

Kachru, Braj B. (1985). Standards, codification and sociolinguistic realism: the English language in the outer circle. In R. Quirk and H. G. Widdowson (eds.), English in the World: Teaching and Learning the Language and Literatures. (pp. 11-30). Cambridge University Press.

Kumaravadivelu, Bala. (2012). Language Teacher Education for a Global Society. New York: Routledge.

Lyiscott, Jamila. (2014). Three Ways to Speak English. Retrieved 24 April at https:// www.ted.com/talks/jamila_lyiscott_3_ways_to_speak_english.

Makoni, Sinfree and Pennycook, Alastair. (2007). Disinventing and reconstituting languages. In S. Makoni and A. Pennycook (eds.), Disinventing and Reconstituting Languages. (pp. 1-41). Clevedon: Multilingual Matters. 
Makoni, Sinfree and Mashiri, Pedzisai. (2007). Critical historiography: does language planning in Africa need a construct of language as part of its theoretical apparatus? In S. Makoni and A. Pennycook (eds.), Disinventing and Reconstituting Languages. (pp. 62-89). Clevedon: Multilingual Matters.

Milroy, James. (1999). The consequences of standardization in descriptive linguistics. In T. Bex and R. J. Watts (eds.), Standard English: The Widening Debate. (pp. 1639). London: Routledge.

Pennycook, Alastair. (2007). The myth of English as an international language. In S. Makoni and A. Pennycook (eds.), Disinventing and Reconstituting Languages. (pp. 90-115). Clevedon: Multilingual Matters.

Pessoa, Rosane R. and Urzêda-Freitas, Marco Túlio de. (2016). Língua como espaço de poder: uma pesquisa de sala de aula na perspectiva crítica. Revista Brasileira de Linguística Aplicada 16: 133-156. Retrieved 5 January at http://www.scielo.br/ pdf/rbla/ v16n1/1984-6398-rbla-20158394.pdf.

Souza, Lynn Mario T. (2011). O professor de inglês e os letramentos no século XXI: métodos ou ética? In C. M. Jordão, J. Z. Martinez and R. C. Halu (eds.). Formação "Desformatada": Práticas com Professores de Língua Inglesa. (pp. 279299). Campinas, SP: Pontes.

Taylor, Tate. (Direction). (2011). The Help. [Motion picture]. The United States of America: DreamWorks Pictures.

Thorne, Steven L. and Lantolf, James P. (2007). A linguistics of communicative activity. In S. Makoni and A. Pennycook (eds.), Disinventing and Reconstituting Languages. (pp. 170-195). Clevedon: Multilingual Matters.

Shaw, Bernard. (2013). Pygmalion. Retrieved 3 August at http://www.feedbooks. com/book/4440/pygmalion. 